\title{
INTERLEUKIN DYNAMICS DURING COGNITIVE STRESS IN PATIENTS WITH CHRONIC CEREBRAL ISCHEMIA
}

Fokin VF凶, Shabalina AA, Ponomareva NV, Medvedev RB, Lagoda OV, Tanashyan MM

Research Center of Neurology, Moscow, Russia

Neuroimmune interactions represent a highly dynamic mechanism for the regulation of cognitive function in chronic cerebral ischemia (CCI). The aim of this study was to investigate changes in salivary proinflammatory cytokines IL $1 \beta$ and IL6 and anti-inflammatory IL10 in patients with CCI (mean age $65.4 \pm 9.1$ years) before and after cognitive tests. After cognitive tests, the levels of salivary IL $1 \beta$ and IL6 were significantly elevated by $101.6 \pm 19.1 \mathrm{pg} / \mathrm{ml}(n=74)$ and $32.8 \pm 6.1 \mathrm{pg} / \mathrm{ml}(n=74)$, respectively. Using one-way ANOVA ana non-parametric statistical methods, we were able to demonstrate associations between changes in salivary interleukins and cognitive performance. In the group of patients with a significant increase in IL1 $\beta$, some cognitive parameters were lower than in the group with negative or zero dynamics of this cytokine: the patients made more mistakes in the subtraction test $(F=11.5 ; n=63 ; p=0.001)$ and performed worse in the Luria test $(F=6.8 ; n=65 ; p=0.01)$. For IL6, Spearman's rank correlation coefficient for the number of mistakes in the subtraction test was positive and differed significantly from $0(R=0.26 ; n=62 ; p=0.042)$. The group with positive IL10 dynamics performed better in $\mathrm{N}$-back test $(F=5.2 ; n=67 ; p=0.03)$ and made fewer mistakes in the subtraction test $(F=6.8 ; n=63 ; p=0.01)$ in comparison with patients who demonstrated negative IL10 dynamics. Good performance in other cognitive tests was not correlated with interleukin dynamics. The article also discusses possible mechanisms underlying interleukin effects on cognitive function in patients with $\mathrm{CCl}$ and applications of the obtained data.

Keywords: neuroimmune interactions, vascular encephalopathy, interleukins, IL1ß, IL6, IL10, cognitive function

Author contribution: Fokin VF performed data analysis and wrote the manuscript; Shabalina AA performed biochemical analysis of cytokines and participated in writing the manuscript; Ponomareva NV collected and analyzed psychometric data, participated in writing the manuscript; Medvedev RB performed clinical examinations, analyzed the literature and proposed the study design; Lagoda OV analyzed clinical data and proposed the study design; Tanashyan MM proposed the study design, summarized clinical data in the context of the obtained results.

Compliance with ethical standards: the study was approved by the Ethics Committee of the Research Center of Neurology (Protocol No. 11/14 dated November 19, 2014); all study participants signed informed consent to participate.

$\triangle$ Correspondence should be addressed: Vitaly F. Fokin

Volokolamskoe shosse, 80, Moscow, 125367; fvf@mail.ru

Received: 06.11.2020 Accepted: 17.12.2020 Published online: 28.12.2020

DOI: $10.24075 / \mathrm{brsmu} .2020 .085$

\section{ИЗМЕНЧИВОСТЬ ИНТЕРЛЕЙКИНОВ ПРИ КОГНИТИВНОЙ НАГРУЗКЕ У БОЛЬНЫХ С ХРОНИЧЕСКОЙ ИШЕМИЕЙ МОЗГА}

В. Ф. Фокин $\bowtie$, А. А. Шабалина, Н. В. Пономарева, Р. Б. Медведев, О. В. Лагода, М. М. Танашян

Научный центр неврологии, Москва, Россия

Нейроиммунное взаимодействие - один из наиболее активных механизмов влияния на когнитивные функции при хронической ишемии мозга (ХИМ). Целью работы было исследовать динамику провоспалительных интерлейкинов в слюне IL $1 \beta$ и IL6, а также противовоспалительного интерлейкина IL10 до и после выполнения когнитивныХ тестов больными XИM (средний возраст 65,4 \pm 9,1 года). После выполнения когнитивных тестов содержание IL $1 \beta$ и IL6 в слюне достоверно увеличилось, соответственно на 101,6 \pm 19,1 пг/мл ( $n=74)$ и 32,8 \pm 6,1 пг/мл ( $n=74)$. С помощью методов дисперсионного анализа (ANOVA) и непараметрической статистики показана сопряженность изменчивости интерлейкинов с успешностью выполнения когнитивных заданий. Так, в группе со значительным приращением IL $1 \beta$ наблюдалось снижение ряда когнитивных показателей по сравнению с группой с более низкой или отрицательной изменчивостью IL1 $\beta$ : большее число ошибок в тесте вычитания $(F=11,5 ; n=63 ; p=0,001)$ и более низкие показатели в тесте Лурия ( $F=6,8 ; n=65 ; p=0,01)$. Коэффициент ранговой корреляции IL6 с количеством ошибок в тесте вычитания был положительным и достоверно отличался от нуля $(R=0,26 ; n=62 ; p=0,042)$. В группе с положительным ростом IL 10 наблюдалось более успешное выполнение корректурного теста ( $F=5,2 ; n=67$; $p=0,03)$, а также меньшее число ошибок в тесте вычитания ( $F=6,8 ; \mathrm{n}=63 ; p=0,01)$, по сравнению с группой больных с отрицательной изменчивостью IL10. Успешность выполнения ряда других когнитивных тестов не была связана с изменчивостью интерлейкинов. Обсуждены возможные механизмы влияния интерлейкинов на когнитивные функции больных ХИМ и практическое использование полученных данных.

Ключевые слова: нейроиммунное взаимодействие, хроническая ишемия мозга, интерлейкины, IL1ß, IL6, IL10, Kогнитивные функции.

Вклад авторов: В. Ф. Фокин - анализ данных, написание статьи; А. А. Шабалина - биохимический анализ цитокинов, участие в написании статьи; Н. В. Пономарева - сбор и анализ психометрических данных, участие в написании статьи; Р. Б. Медведев - клинические обследования, анализ литературы, дизайн исследования; О. В. Лагода - анализ клинических данных, дизайн исследования; М. М. Танашян - дизайн исследования, обобщение клинического материала в контексте полученных результатов.

Соблюдение этических стандартов: исследование одобрено этическим комитетом Научного центра неврологии (протокол № 11/14 от 19 ноября 2014 г.); все участники подписали информированное согласие на участие в исследовании.

$\triangle$ Для корреспонденции: Виталий Федорович Фокин Волоколамское ш., д. 80, г. Москва, 125367; fvf@mail.ru

Статья получена: 06.11.2020 Статья принята к печати: 17.12.2020 Опубликована онлайн: 28.12.2020

DOI: $10.24075 /$ vrgmu.2020.085

Exploration of molecular mechanisms implicated in cognitive disorders is the leading area of neurological research [1]. Progressive cognitive decline culminating in dementia is the main health issue arising from vascular and neurodegenerative diseases, most of which are associated with advancing age.
Being a part of normal aging, gradual cerebral ischemia and atrophy in elderly patients can be considered pathologic, as compared with younger age groups, since they also lead to cognitive decline. Vascular disorders and aging are accompanied by chronic inflammation maintained by the 
immune system. Neuroimmune interactions are the crucial component of the underlying pathogenetic mechanism as they largely determine the course of the disease and the level of cognitive functioning [2-8].

Understanding the pattern of changes in the salivary concentrations of pro-inflammatory interleukins (IL1 $\beta$, IL6 and IL10) in response to cognitive stress is an important avenue of contemporary neuroimmunology research. Chronic cerebral ischemia $(\mathrm{CCl})$ is a pathological form of vascular aging, i.e. progredient chronic vascular insufficiency accompanied by non-focal neurological symptoms and cognitive decline caused by cortical or subcortical lacunar infarcts. Ischemia triggers inflammation, production of reactive oxygen species and activation of microglia and other glial cells, thereby stimulating secretion of cytokines including proinflammatory interleukins $[9,10]$.

Proinflammatory interleukin IL $1 \beta$ plays a role in inflammatory response and other immune processes; its modulatory effects span the nervous, immune and endocrine systems. IL1 $\beta$ and its receptors are present in the brain and especially abundant in the hippocampus. There are reasons to believe that IL $1 \beta$ is involved in the modulation of hippocampal plasticity and memory formation [4]. According to the majority of IL1 $\beta$ studies, elevated IL1 $\beta$ has a negative impact on cognitive function. However, some studies report that IL1 $\beta$ either does not affect or has a beneficial effect on learning and memory. Physiological concentrations of IL $1 \beta$ promote post-tetanic potentiation but its abnormally high levels can be inhibitory and interfere with learning and memory. Furthermore, IL1 $\beta$, IL6 and a few other cytokines are activated in the brain upon induction of longterm potentiation [5]. It is reported that central administration of IL1 $\beta$ to rats affects inflammatory response and enhances conditioned memory; this cognitive effect is correlated with glucocorticoid levels [6]. In addition, IL1 $\beta$ can interact with the autonomic nervous system [7], which, in turn, may mediate its effects on cognition.

Interleukin 6 (IL6) is one of the major mediators of acute inflammation. The sources of IL6 in the central nervous system are represented by neurons, astrocytes, microglia and endothelial cells. IL6 plays a definitive role in the pathogenesis of inflammatory diseases and the normal homeostasis of nervous tissue [8].

Recently, IL6 has been hypothesized as having an impact on cognitive function. Some researchers applied the analysis of variance to identify factors affecting the levels of IL6. Age, hypertension, diabetes, smoking, moderate consumption of alcohol, total homocysteine, carotid intima-media thickness and body mass index were reported to be positively correlated with IL6 concentrations. In a multidimensional linear regression model, IL6 was negatively correlated with Mini mental state examination scores adjusted for social, economic and vascular risk factors. It is known that IL6 can be expressed by brain cells, including neurons during their depolarization [11]. Perhaps, this process can be activated by cognitive stress.

Elevated IL6 is observed in patients with declining cognitive function, which may be associated with the regulation of posttetanic potentiation $[12,13]$. Similar to IL1 $\beta$, IL6 interacts with the autonomous nervous system [14].

IL10 is an anti-inflammatory cytokine that inhibits secretion of proinflammatory IL $1 \beta$, IL6 and tumor necrosis factor alpha (TNF $\alpha)$ and stimulates release of other anti-inflammatory cytokines, including the IL $1 \beta$ receptor antagonist, which exerts anti-inflammatory effects. IL10 reduces IL1 $\beta$ and TNF $\alpha$ levels after traumatic brain injury in rats and improves neurologic recovery [15]. Hyperactive microglial response observed in persistent inflammation is often associated with increased expression of inflammatory IL1 $\beta$ and anti-inflammatory IL10 [16], which often occurs in the setting of sympathetic nervous system activation [17]. IL10 blocks the inhibitory effect of IL1 $\beta$ on post-tetanic potentiation [18].

We hypothesize that interleukin effects on cognitive function are characterized by certain selectivity and mostly target longterm memory.

The aim of this study was to assess associations between cognitive processes and the dynamics of pro- and antiinflammatory interleukins in patients with $\mathrm{CCl}$.

\section{METHODS}

The study recruited 31 male and 63 female patients with $\mathrm{CCl}$ aged 42 to 85 years (the mean age was $65.4 \pm 9.1$ years). Pathomorphologically, cognitive decline in patients with $\mathrm{CCl}$ is characterized by the presence of diffuse and multiple lacunar lesions in the subcortical white matter and the cortex; subcortical defects are often associated with either cerebral atherosclerosis or lipohyalinosis of small penetrating arteries supplying deeper brain regions. Etiologically, CCI has a variety of causes, including atherosclerosis, high blood pressure and hypertensive heart disease, venous insufficiency, diabetic angiopathy, vasculitis of various etiology, hematologic disorders, etc. Our patients with $\mathrm{CCl}$ and cognitive decline differed in the extent of memory impairment, ability to work, irritability, brainstem symptoms, etc. The following inclusion criteria were applied: stage I-II dyscirculatory encephalopathy (early or subcompensation stage according to the classification by Levin OS [19-20]); right-handedness; MoCa scores of $\geq 26$ (patients who scored $<26$ were included in the study if they were not demented and did not need daily care). Exclusion criteria: pronounced dementia ( $\geq 1$ points on the Clinical Dementia Rating Scale); a history of acute cerebrovascular accidents; traumatic brain injury; severe cardiac or metabolic (type 2 diabetes mellitus) pathology; renal insufficiency; uncompensated thyroid dysfunction.

The patients underwent a battery of tests to assess their cognitive function. The tests were performed in strict sequence. The first task was an alphabetic version of the N-back test: the patients were asked to find all occurrences of a specified two-letter combination in a text without space characters in 3 minutes. This test is based on the Kirchner n-back task with $n=1$. As a rule, healthy subjects are able to complete this task without or with only one mistake.

The $\mathrm{N}$-back test was followed by a verbal fluency test: the patients were asked to name as many words as possible starting with each of the specified Russian letters ( $C, K$ and $A$ ). The number of words was summarized and averaged.

The next test initially proposed by Luria aimed to assess verbal memory. First, the patients were asked to memorize and recall 10 words (each series of words was repeated 5 times). Then, the patients counted backwards from 100 by sevens. Finally, the patients were asked again to reproduce the memorized words. Immediate and delayed scores were counted. Healthy subjects were able to remember 9-10 words in the immediate recall test, made no mistakes in the subtraction test, and reproduced 8-10 words in the delayed recall test.

Overall cognitive function and patient eligibility for the study were assessed using the Montreal cognitive assessment scale (MoCa).

Salivary interleukins were measured before and after cognitive tests by means of a sandwich ELISA. IL10 was measured using eBioscience reagents (Bender MedSystems; Austria); IL1 $\beta$ and IL6 concentrations were determined using reagents by Vector-Best (Russia). The detection range was from 1 to $2,000 \mathrm{pg} / \mathrm{mL}$. Assay calibrators were purchased from the 
Table 1. Statistical characteristics of interleukin levels before and after cognitive tests

\begin{tabular}{|l|c|c|c|c|c|}
\hline \multicolumn{1}{|c|}{ Variable } & $n$ & Mean, $\mathrm{pg} / \mathrm{ml}$ & Standard deviation, $\mathrm{pg} / \mathrm{ml}$ & Standard error, $\mathrm{pg} / \mathrm{ml}$ & $p$ \\
\hline IL1 $\beta$, before & 94 & 584.9468 & 275.1798 & 28.38263 & $<0.000001$ \\
\hline IL1 $\beta$, after & 74 & 678.9865 & 272.2785 & 31.65174 & $<0.000001$ \\
\hline IL $\beta$, shift & 74 & 101.6216 & 170.5874 & 19.83039 & 0.000002 \\
\hline IL6, before & 94 & 152.5894 & 66.2574 & 6.83393 & $<0.000001$ \\
\hline IL6, after & 74 & 191.2527 & 88.2664 & 10.26076 & $<0.000001$ \\
\hline IL6, shift & 74 & 32.8459 & 52.4934 & 6.10223 & 0.000001 \\
\hline IL10, before & 92 & 0.9592 & 0.1949 & 0.02032 & $<0.000001$ \\
\hline IL10, after & 74 & 0.9159 & 0.2505 & 0.02912 & $<0.000001$ \\
\hline IL10, shift & 74 & -0.0177 & 0.2047 & 0.02379 & 0.459261 \\
\hline
\end{tabular}

Note: $p$ — level of statistical significance.

manufacturers of the reagent kits. All assays were performed in duplicates in a VICTOR 2 plate reader (Perken Elmer; USA); samples with low and high analyte content were used for control. Salivary specimens were collected before and after cognitive tests using a previously published protocol [21]. The patients were asked not to drink alcohol in the week preceding saliva collection and to abstain from tea and coffee one hour before saliva collection. Ten minutes before sample collection, the patients rinsed their mouths with water. Saliva was spat into a test tube of at least $1.5 \mathrm{~m}$ in volume. Saliva specimens were collected 10 min before cognitive tests and no later than 10 min after the tests were completed. Specimens were tested for blood contamination using ELISA. Contaminated specimens were excluded from the analysis.

The obtained data were processed in Statistica-12 (Dell; USA). Normality of distribution was assessed using the Kolmogorov-Smirnov test. Arithmetic means, standard deviations, standard errors and variance were calculated; one-way ANOVA and correlation analysis were applied. Non-parametric Spearman's rank correlation was applied to compare variables with non-normal distribution.

One-way ANOVA was applied to investigate associations between interleukin reactivity to cognitive stress and patient scores. For that, the patients were divided into groups based on whether changes in interleukin concentrations were below or above the average level. Because average changes in IL10 concentrations did not differ from zero, data on IL10 were arranged into a negative and positive shift groups.

\section{RESULTS}

The dynamics of IL1 $\beta$, IL6 and IL10 levels did not differ significantly between the two sexes, therefore interleukin response was analyzed in the mixed group of male and female participants. Baseline interleukin concentrations in salivary specimens were correlated with age: $r=0.25, n=94, p=0.031$ and $r=0.21, n=94, p=0.041$, respectively. Changes in IL1 $\beta$ and IL6 concentrations following cognitive tests were not correlated with age; for IL 10 , this correlation was weak: $r=0.24$, $p=0.042, n=74$.

Statistical characteristics of interleukin levels is provided in Table 1.

For IL10, the delta value did not differ significantly from zero, in contrast to other mean values.

The Kolmogorov-Smirnov test showed that the distribution of a random variable for IL $1 \beta$ and IL10 did not differ from normal, in contrast to IL6. Data on IL1 $\beta$ and IL10 were subjected to one-way ANOVA. The cumulative data on the dynamics of IL1 $\beta$ and IL10 were arranged in 2 groups: above and below average values. Mean shifts in IL1 $\beta$ and IL10 concentrations in these groups are shown in Table 2. The groups did not differ in terms of age.

Changes in IL1 $\beta$ concentrations in group 1 did not differ significantly from zero, while in other cases the shifts were statistically significant (see Table 2). Differences between the groups were significant for IL1 $\beta$ and IL10: $F=81.6$ at $p<0.000001$ and $F=147.8$ at $p<0.000001$, respectively.

The next step involved the analysis of the associations between the measured cognitive parameters and shifts in IL1 $\beta$ and IL10 concentrations after cognitive tests.

A positive shift (increase) in IL1 $\beta$ concentrations demonstrated by group 2 was correlated with less successful performance during cognitive tests (Table 3, Fig. 1).

Changes in anti-inflammatory IL10 were also associated with cognitive function, but the established association was opposite to that discovered for proinflammatory IL1 $\beta$ and IL6: the more pronounced response of IL10 was correlated with better performance during cognitive tests (Table 4; Fig. 2).

"Detected patterns" refer to the specified 2-letter combinations found by the patients in the alphabetic N-back test.

Fig. 2 provides a graphic representation of differences in cognitive indicators associated with shifts in IL10 concentrations.

Table 2. Shifts in IL $1 \beta$ and IL10 salivary concentrations following cognitive stress in 2 groups of patients

\begin{tabular}{|l|c|c|c|c|}
\hline & Mean IL1 $\beta, \mathrm{pg} / \mathrm{ml}$ & Standard error IL1 $\beta, \mathrm{pg} / \mathrm{ml}$ & Mean IL10, pg/ml & Standard error IL10, pg/ml \\
\hline Group 1 (below average) & $-0.34(n=44)$ & $14.7(p=0,98)$ & $-0.10(n=40)$ & $0.02(p<0,00001)$ \\
\hline Group 2 (above average) & $251.2(n=30)$ & $26.8(p<0,00001)$ & $0.13(n=33)$ & $0.02(p<0,00001)$ \\
\hline
\end{tabular}

Note: $p$ - level of statistical significance.

Table 3. Associations between shifts in IL1 $\beta$ concentrations and cognitive function

\begin{tabular}{|l|l|c|c|}
\hline \multicolumn{1}{|c|}{ IL1 $\beta$} & $n$ & $F$ \\
\hline Subtraction (100-7) & 63 & 11.49 \\
\hline Delayed recall (based on Luria tests) & 65 & 0.001 \\
\hline
\end{tabular}

Note: F — Fisher's coefficient; $p$ — level of significance. 
A

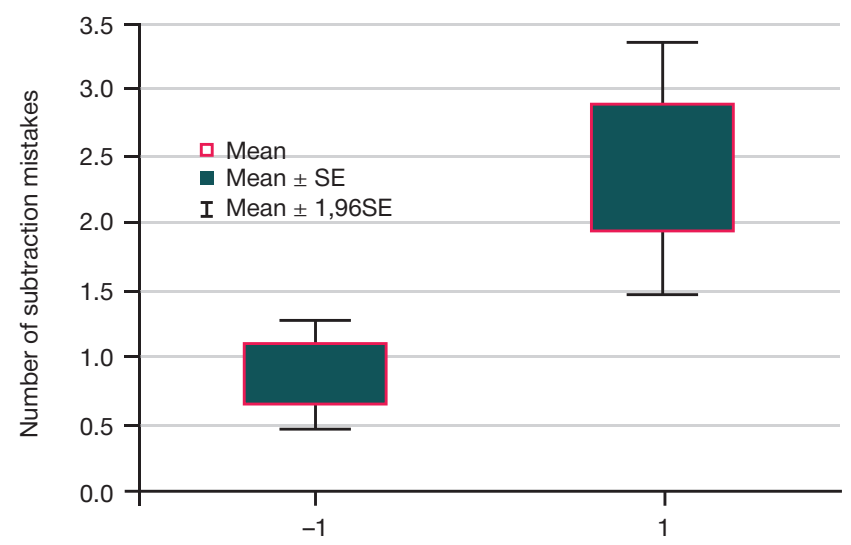

B

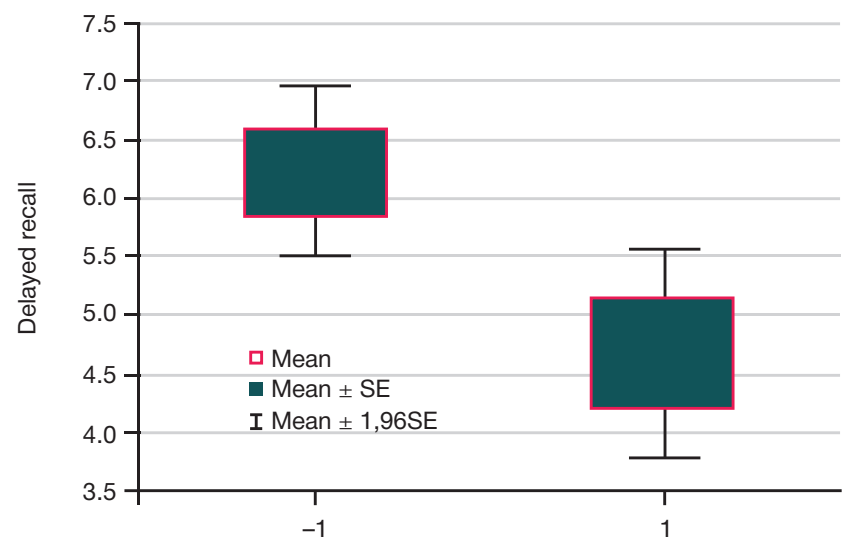

Fig. 1. Performance during cognitive tests in groups 1 and 2 of IL $1 \beta$ shifts. -1 - group $1,1-$ group 2. A. Number of subtraction mistakes (100-7). B. Delayed words recall in the Luria test

Comparison of figures 1 and 2 reveals that cognitive function is negatively correlated with pro- and anti-inflammatory interleukin response.

The Kolmogorov-Smirnov test demonstrated that IL6 shifts did not conform with normal distribution; therefore, associations between IL6 shifts and cognitive function were measured by Spearman's rank correlation used for nonparametric samples. Spearman's correlation coefficient for the subtraction test and IL6 shifts significantly differed from zero $(r=0.26 ; n=62$; $p=0.042$ ). Similar to IL1 $\beta$, the higher number of mistakes was associated with a higher increase in IL6 levels.

Some cognitive indicators were insensitive to changes in interleukin concentrations, including $\mathrm{MoCa}$, verbal fluency and immediate recall (Luria) scores.

\section{DISCUSSION}

Reported physiological salivary concentrations of interleukins in general and IL10 in particular vary across studies [22-23]. In people of advancing age, salivary interleukin levels are affected by a multitude of factors, from the past history of diseases to the quality and number of dentures. So, it may be reasonable to analyze and compare relative indicators within one group of patients; some authors rely on the ratios of different proinflammatory cytokines, for example, IL1 $\beta$ to IL10, or measure interleukin response to stress. Proinflammatory interleukins, including IL10, are elevated in the setting of stress [23]. Cognitive tests cause an elevation of IL1 $\beta$ and IL6 levels, but induce no changes in IL10 concentrations. The absence of IL10 dynamics in response to cognitive tests can be explained by weak stress limited to sympathoadrenal activation.

Many proteins originally detected in the immune system are also found in neuronal synapses participating in cognitive processes [24]. Our work demonstrates an increase in salivary interleukins during cognitive tests in patients with $\mathrm{CCl}$. Higher expression of proinflammatory cytokines was correlated with worse performance in cognitive tests. Patients with $\mathrm{CCl}$ had more pronounced inflammation in comparison with healthy individuals [25]. In such patients, neuronal activation enhances secretion of proinflammatory interleukins, but the intensity of this enhancement depends on the severity of the disease. It is known that sympathetic neurons secrete IL6 and produce paracrine or autocrine signals in response to the presence of the soluble IL6 receptor [26]. So, hypothetically neuronal activation in patients with $\mathrm{CCl}$ will be accompanied by an increase in the levels of proinflammatory interleukins. It is known that proinflammatory cytokines disrupt normal neuronal function in an adult brain by exerting a direct effect on neurons or by triggering mechanisms mediated by non-neuronal cells (like microglia or astrocytes) [27]. Patients with $\mathrm{CCl}$ will inevitably experience mild stress during cognitive testing because they perceive cognitive tasks as psychoemotional strain. Stress might trigger cytokine secretion (IL1 $\beta$, IL6, etc.) On the one hand, physiological levels of IL1 $\beta$ are indispensable to learning and memorizing; on the other hand, elevated IL $1 \beta$ is detrimental to cognitive performance. Increased production of IL6 in the setting of stress exacerbates inflammation by stimulating IL $1 \beta$ secretion in the brain and thus promotes anxiety [28]. Effects of IL $1 \beta$ on memory and learning are often associated with its effects on synaptic mechanisms of long-term potentiation in the hippocampus. IL1 $\beta$ induces hyperpolarization and modulates synaptic inhibition of preoptic and frontal hypothalamic neurons; it also neutralizes long-term depression of synaptic transmission in the hippocampus. The cytokine network consisting of IL1 $\beta$, IL18, IL6 and TNFa interacts with neurons during long-term potentiation and learning. Blockade of endogenous IL1 $\beta$ is beneficial to memory formation [29].

Effects exerted by IL10 are opposite to those of proinflammatory cytokines. It is known that IL10 is involved in cytokine regulation (feedback loop) and inhibits effects of proinflammatory cytokines. This interleukin demonstrated no significant dynamics during cognitive stress, which might be explained by its low involvement in cognitive processes as such. The impact of IL10 on cognitive function might be mediated by its effects on proinflammatory IL $1 \beta$ and IL6 [30].

Cognitive performance correlated with changes in interleukin concentrations was reflective of memory retention, i.e. plasticity processes. Notably, immediate word recall in the Luria test was not associated with changes in the levels of proinflammatory interleukins, whereas delayed word recall was associated with

Table 4. Associations between IL10 response and cognitive function

\begin{tabular}{|l|c|c|c|}
\hline \multicolumn{1}{|c|}{ IL10 } & $n$ & $F$ & $p$ \\
\hline Subtraction (100-7) & 63 & 6.83 & 0.01 \\
\hline Detected patterns & 67 & 5.16 & 0.026 \\
\hline
\end{tabular}

Note: $F$ - Fisher's coefficient; $p$ — level of significance. 

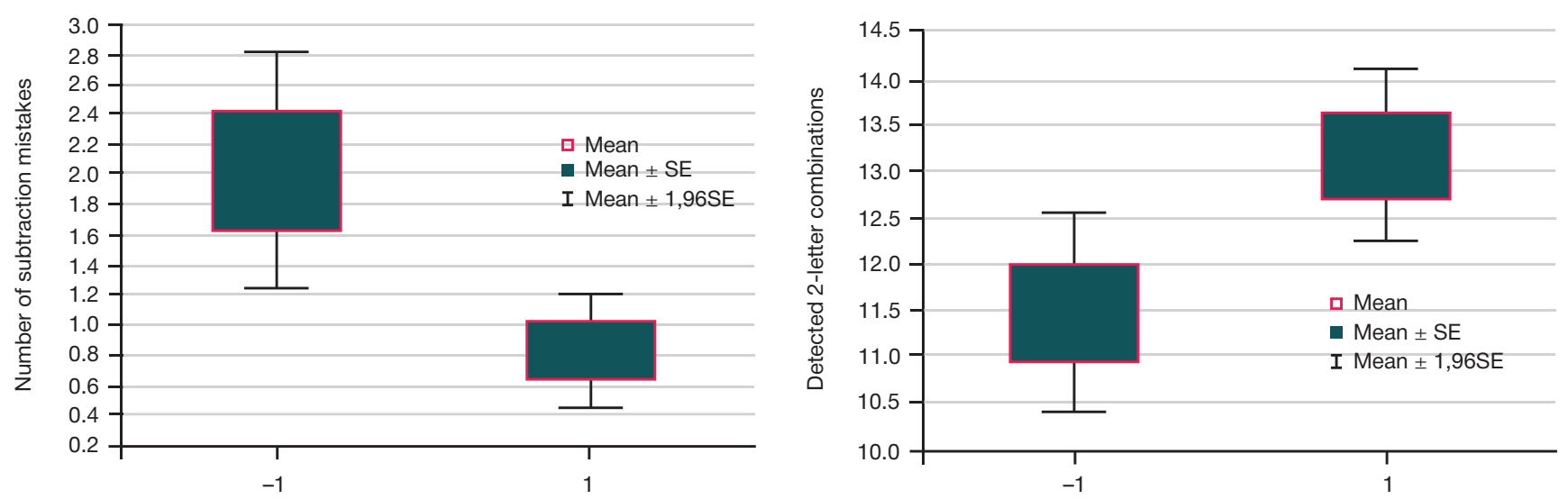

Fig. 2. Cognitive test performance in patients with negative or positive IL10 response. The legend is the same as in Fig. 1

changes in IL1 $\beta$. This confirms the potential role of IL1 $\beta$ in inhibiting post-tetanic potentiation. Perhaps, this mechanism underlies many effects of proinflammatory interleukins.

Our findings may be clinically useful. Current recommendations for people of advancing age struggling with chronic vascular diseases point to the benefits of intense cognitive load (doing crossword puzzles, studying foreign languages, etc.) Our findings suggest that in some cases cognitive load can lead to elevated proinflammatory cytokines and contribute to oxidative stress, which raises questions about the benefits of such recommendations. Further research could be aimed at exploring biological markers of proinflammatory interleukins that could be conveniently used for controlling cognitive load and monitoring the response of proinflammatory cytokines.

\section{CONCLUSION}

The dynamics of pro- and anti-inflammatory interleukins IL $1 \beta$, IL6 and IL10 were associated with performing cognitive tasks in patients with $\mathrm{CCl}$. Cognitive stress was accompanied by the reliable increase in IL1 $\beta$ and IL6 in the mixed sample of men and women. Changes in the levels of all studied cytokines reflected performance scores. Elevated salivary IL1 $\beta$ and IL6 were associated with worse performance in the subtraction test (100-7); heightened IL1 $\beta$ was associated with poor scores in the delayed recall test. Patients with positive dynamics of salivary IL10 made fewer mistakes in the subtraction test and did better in the N-back test than patients with negative IL10 dynamics. Thus, the significant increase in the levels of salivary proinflammatory cytokines induced by cognitive stress was accompanied by a decline in cognitive function in delayed memory tests, while similar changes in anti-inflammatory IL10 were associated with better cognitive performance. MoCa, verbal fluency and some other scores were not associated with changes in interleukin levels. Further discussion is needed to understand the mechanisms underlying interleukin effects on cognitive function. There is a tight link between the levels of proinflammatory cytokines and some types of mental activity, suggesting that patients with $\mathrm{CCl}$ should be monitored for the levels of proinflammatory cytokines during cognitive tasks.

\section{References}

1. Suslina ZA, Illarioshkin SN, Piradov MA. Nevrologija i nejronauki prognoz razvitija. Annaly klinicheskoj i jeksperimental'noj nevrologii. 2007; 1 (1): 5-9. Russian.

2. Fokin VF, Ponomareva NV, Androsova LV, Selezneva ND. Vzaimodejstvie nervnoj i immunnoj sistem pri normal'nom starenii i demencijah al'cgejmerovskogo tipa. Fiziologija cheloveka. 1996; 26 (6): 55-59. Russian.

3. Ponomareva NV, Androsova LV, Klyushnikov SA, Abramycheva NYu, Malina DD, Filippova YuV, i dr. Narushenie nejro-immunnogo vzaimodejstvija na preklinicheskoj stadii bolezni Gentingtona i ego rol' v razvitii zabolevanija. Rukovodstvo dlja vrachej. V sbornike: Materialy HH Kongressa po nevrologii pod red. S. N. Illarioshkina i O. S. Levina. Moskva, 2017; s. 253-7. Russian.

4. Huang ZB, Sheng GQ. Interleukin- $1 \beta$ with learning and memory. Neurosci Bull. 2010; 26 (6): 455-68. DOI: 10.1007/s12264-0106023-5.

5. Erickson MA, Banks WA. Neuroimmune Axes of the Blood-Brain Barriers and Blood-Brain Interfaces: Bases for Physiological Regulation, Disease States, and Pharmacological Interventions. Pharmacol Rev. 2018; 70 (2): 278-314. DOI: 10.1124/pr.117.014647.

6. Song C, Phillips AG, Leonard B. Interleukin 1 beta enhances conditioned fear memory in rats: possible involvement of glucocorticoids. Eur J Neurosci. 2003; 18: 1739-43. DOI: 10.1046/j.1460-9568.2003.02886.x.

7. Haefeli WE, Bargetzi MJ, Starnes HF, Blaschke TF, Hoffman BB. Evidence for activation of the sympathetic nervous system by

recombinant human interleukin-1 beta in humans. J Immunother Emphasis Tumor Immunol. 1993 Feb; 13 (2): 136-40. DOI: 10.1097/00002371-199302000-00009. PMID: 8318499.

8. Erta M, Quintana A, Hidalgo J. Interleukin-6, a major cytokine in the central nervous system. Int J Biol Sci. 2012; 8 (9): 1254-66. DOI: 10.7150/ijbs.4679. Epub 2012 Oct 25. PMID: 23136554; PMCID: PMC3491449.

9. Batysheva TT, Artemova IYu, Vdovichenko TV. Hronicheskaja ishemija mozga: mehanizmy razvitija i sovremennoe kompleksnoe lechenie. Consilium medicum 2004; 3 (4). Dostupno po ssylke: http://old.consilium-medicum.com/media/refer/04_04/51.shtml. Russian.

10. ladecola $C$, Alexander M. Cerebral ischemia and inflammation. Curr Opin Neurol. 2001 Feb; 14 (1): 89-94. DOI: 10.1097/00019052200102000-00014. PMID: 11176223.

11. Sallmann $S$, Jüttler $E$, Prinz $S$, et al. Induction of Interleukin-6 by Depolarization of Neurons. Journal of Neuroscience 1 December 2000; 20 (23): 8637-42; DOI: 10.1523/ JNEUROSCI.20-23-08637.2000.

12. Balschun D, Wetzel W, Del Rey A, Pitossi F, Schneider H, Zuschratter W, Besedovsky HO. Interleukin-6: a cytokine to forget. FASEB J. 2004 Nov; 18 (14): 1788-90. DOI: 10.1096/ fj.04-1625fje. PMID: 15345694.

13. Wright CB, Sacco RL, Rundek T, Delman J, Rabbani L, Elkind M. Interleukin-6 is associated with cognitive function: The Northern Manhattan Study. J Stroke Cerebrovasc Dis. 2006; 15 (1): 34-38. 
DOI: 10.1016/j.jstrokecerebrovasdis.2005.08.009.

14. Helwig BG, Craig RA, Fels RJ, Blecha F, Kenney MJ. Central nervous system administration of interleukin- 6 produces splenic sympathoexcitation. Auton Neurosci. 2008; 141 (1-2): 104-11. DOI: 10.1016/j.autneu.2008.04.008.

15. Moore KW, de Waal Malefyt R, Coffman RL, O'Garra A Interleukin-10 and the interleukin-10 receptor. Annu Rev Immunol. 2001; 19: 683-765.

16. Henry C, Huang Y, Wynne AM, Godbout JP. Peripheral lipopolysaccharide (LPS) challenge promotes microglial hyperactivity in aged mice that is associated with exaggerated induction of both pro-inflammatory $\mathrm{IL}-1$ [beta] and antiinflammatory IL-10 cytokines. Brain Behav Immun. 2009; 23: 309.

17. Woiciechowsky C, Schöning B, Lanksch WR, et al Catecholamine-induced interleukin-10 release: a key mechanism in systemic immunodepression after brain injury. Crit Care. 1999; 3: R107. Available from: https://doi.org/10.1186/cc375.

18. Kelly A, Lynch A, Vereker E, Nolan Y, Queenan P, Whittaker E, O'Neill LA, Lynch MA. The anti-inflammatory cytokine, interleukin (IL)-10, blocks the inhibitory effect of IL-1 beta on long term potentiation. A role for JNK. J Biol Chem. 2001 Dec 7; 276 (49): 45564-72. DOI: 10.1074/jbc.M108757200. PMID: 11581275.

19. Levin OS. Discirkuljatornaja jencefalopatija: sovremennye predstavlenija o mehanizmah razvitija i lechenii. Consilium medicum. 2007; 8: 72-79. Russian.

20. Tanashyan MM, Maksimova MYu, Domashenko MA. Discirkuljatornaja jencefalopatija. Putevoditel' vrachebnyh naznachenij. Terapevticheski] spravochnik. 2015; 2: 1-25. Russian.

21. La Fratta I, Tatangelo R, Campagna G, et al. The plasmatic and salivary levels of $\mathrm{IL}-1 \beta, \mathrm{IL}-18$ and $\mathrm{IL}-6$ are associated to emotional difference during stress in young male. Sci Rep. 2018; 8 (1): 3031
DOI: 10.1038/s41598-018-21474-y. PMID: 29445205; PMCID: PMC5813044.

22. Szabo YZ, Newton TL, Miller JJ, Lyle KB, Fernandez-Botran R. Acute stress induces increases in salivary IL-10 levels. Stress. 2016; 19 (5): 499-505. DOI: 10.1080/10253890.2016.1206885.

23. Rezazadeh F, Shahbazi F, Andisheh-Tadbir A. Evaluation of salivary level of IL-10 in patients with oral lichen planus, a preliminary investigation. Comp Clin Pathol. 2017; 26: 531-4. Available from: https://doi.org/10.1007/s00580-017-2415-5.

24. Nisticò R, Salter E, Nicolas C, et al. Synaptoimmunology — roles in health and disease. Mol Brain. 2017; 10: 26. Available from: https://doi.org/10.1186/s13041-017-0308-9.

25. Liu F, Mccullough L. Inflammatory responses in hypoxic ischemic encephalopathy. Acta Pharmacol Sin. 2013; 34: 1121-30. Available from: https://doi.org/10.1038/aps.2013.89.

26. März P, Cheng JG, Gadient RA, et al. Sympathetic neurons can produce and respond to interleukin 6. Proc Natl Acad Sci USA. 1998; 95 (6): 3251-6. DOI: 10.1073/pnas.95.6.3251.

27. Liu X, Quan N. Microglia and CNS Interleukin-1: Beyond Immunological Concepts Front Neurol. 2018; 9: 8. DOI: 10.3389/ fneur.2018.00008.

28. Gruol DL. IL-6 regulation of synaptic function in the CNS. Neuropharmacology. 2015 Sep; 96 (Pt A): 42-54. DOI: 10.1016/j. neuropharm.2014.10.023.

29. Sparkman NL, Johnson RW. Neuroinflammation associated with aging sensitizes the brain to the effects of infection or stress. Neuroimmunomodulation. 2008; 15: 323-30.

30. Lobo-Silva D, Carriche GM, Castro AG, et al. Balancing the immune response in the brain: $\mathrm{IL}-10$ and its regulation. $J$ Neuroinflammation. 2016; 13: 297. Available from: https://doi. org/10.1186/s12974-016-0763-8.

\section{Литература}

1. Суслина 3. А., Иллариошкин С. Н., Пирадов М. А. Неврология и нейронауки - прогноз развития. Анналы клинической и экспериментальной неврологии. 2007; 1 (1): 5-9.

2. Фокин В. Ф., Пономарева Н. В., Андросова Л. В., Селезнева Н. Д. Взаимодействие нервной и иммунной систем при нормальном старении и деменциях альцгеймеровского типа. Физиология человека. 1996; 26 (6): 55-59.

3. Пономарева Н. В., Андросова Л. В., Клюшников С. А. Абрамычева Н. Ю, Малина Д. Д., Филиппова Ю. В. и др. Нарушение нейро-иммунного взаимодействия на преклинической стадии болезни Гентингтона и его роль в развитии заболевания. Руководство для врачей. В сборнике: Материалы XX Конгресса по неврологии под ред. С. Н. Иллариошкина и О. С. Левина. Москва, 2017; с. 253-7.

4. Huang ZB, Sheng GQ. Interleukin-1 $\beta$ with learning and memory. Neurosci Bull. 2010; 26 (6): 455-68. DOI: 10.1007/s12264-0106023-5.

5. Erickson MA, Banks WA. Neuroimmune Axes of the Blood-Brain Barriers and Blood-Brain Interfaces: Bases for Physiological Regulation, Disease States, and Pharmacological Interventions. Pharmacol Rev. 2018; 70 (2): 278-314. DOI: 10.1124/pr.117.014647.

6. Song C, Phillips AG, Leonard B. Interleukin 1 beta enhances conditioned fear memory in rats: possible involvement of glucocorticoids. Eur J Neurosci. 2003; 18: 1739-43. DOl: 10.1046/.j.1460-9568.2003.02886.x.

7. Haefeli WE, Bargetzi MJ, Starnes HF, Blaschke TF, Hoffman BB. Evidence for activation of the sympathetic nervous system by recombinant human interleukin-1 beta in humans. J Immunother Emphasis Tumor Immunol. 1993 Feb; 13 (2): 136-40. DOI: 10.1097/00002371-199302000-00009. PMID: 8318499.

8. Erta M, Quintana A, Hidalgo J. Interleukin-6, a major cytokine in the central nervous system. Int J Biol Sci. 2012; 8 (9): 1254-66. DOI: 10.7150/ijbs.4679. Epub 2012 Oct 25. PMID: 23136554; PMCID: PMC3491449.

9. Батышева Т. Т, Артемова И. Ю., Вдовиченко Т. В. Хроническая ишемия мозга: механизмы развития и современное комплексное лечение. Consilium medicum 2004; 3 (4).

Доступно по ссылке: http://old.consilium-medicum.com/media/ refer/04_04/51.shtml.

10. ladecola $\mathrm{C}$, Alexander $\mathrm{M}$. Cerebral ischemia and inflammation. Curr Opin Neurol. 2001 Feb; 14 (1): 89-94. DOI: 10.1097/00019052200102000-00014. PMID: 11176223

11. Sallmann $\mathrm{S}$, Jüttler $\mathrm{E}$, Prinz $\mathrm{S}$, et al. Induction of Interleukin-6 by Depolarization of Neurons. Journal of Neuroscience 1 December 2000; 20 (23): 8637-42; DOI: 10.1523/ JNEUROSCI.20-23-08637.2000.

12. Balschun D, Wetzel W, Del Rey A, Pitossi F, Schneider $H$, Zuschratter W, Besedovsky HO. Interleukin-6: a cytokine to forget. FASEB J. 2004 Nov; 18 (14): 1788-90. DOI: 10.1096/ fj.04-1625fje. PMID: 15345694.

13. Wright CB, Sacco RL, Rundek T, Delman J, Rabbani L, Elkind M. Interleukin-6 is associated with cognitive function: The Northern Manhattan Study. J Stroke Cerebrovasc Dis. 2006; 15 (1): 34-38. DOI: 10.1016/j.jstrokecerebrovasdis.2005.08.009.

14. Helwig BG, Craig RA, Fels RJ, Blecha F, Kenney MJ. Central nervous system administration of interleukin- 6 produces splenic sympathoexcitation. Auton Neurosci. 2008; 141 (1-2): 104-11. DOI: 10.1016/j.autneu.2008.04.008.

15. Moore KW, de Waal Malefyt R, Coffman RL, O'Garra A. Interleukin-10 and the interleukin-10 receptor. Annu Rev Immunol. 2001; 19: 683-765.

16. Henry C, Huang Y, Wynne AM, Godbout JP. Peripheral lipopolysaccharide (LPS) challenge promotes microglial hyperactivity in aged mice that is associated with exaggerated induction of both pro-inflammatory $\mathrm{IL}-1$ [beta] and antiinflammatory IL-10 cytokines. Brain Behav Immun. 2009; 23: 309.

17. Woiciechowsky C, Schöning B, Lanksch WR, et al. Catecholamine-induced interleukin-10 release: a key mechanism in systemic immunodepression after brain injury. Crit Care. 1999; 3: R107. Available from: https://doi.org/10.1186/cc375.

18. Kelly A, Lynch A, Vereker E, Nolan Y, Queenan P, Whittaker E, O'Neill LA, Lynch MA. The anti-inflammatory cytokine, interleukin (IL)-10, blocks the inhibitory effect of IL-1 beta on long term potentiation. A role for JNK. J Biol Chem. 2001 Dec 7; 276 (49): 45564-72. DOI: 10.1074/jbc.M108757200. PMID: 11581275. 
19. Левин О. С. Дисциркуляторная энцефалопатия: современные представления о механизмах развития и лечении. Consilium medicum. 2007; 8: 72-79.

20. Танашян М. М., Максимова М. Ю., Домашенко М. А. Дисциркуляторная энцефалопатия. Путеводитель врачебных назначений. Терапевтический справочник. 2015; 2: 1-25.

21. La Fratta I, Tatangelo R, Campagna G, et al. The plasmatic and salivary levels of IL-1 $\beta$, IL-18 and IL-6 are associated to emotional difference during stress in young male. Sci Rep. 2018; 8 (1): 3031. DOI: 10.1038/s41598-018-21474-y. PMID: 29445205; PMCID: PMC5813044.

22. Szabo YZ, Newton TL, Miller JJ, Lyle KB, Fernandez-Botran R. Acute stress induces increases in salivary IL-10 levels. Stress. 2016; 19 (5): 499-505. DOI: 10.1080/10253890.2016.1206885.

23. Rezazadeh F, Shahbazi F, Andisheh-Tadbir A. Evaluation of salivary level of IL-10 in patients with oral lichen planus, a preliminary investigation. Comp Clin Pathol. 2017; 26: 531-4. Available from: https://doi.org/10.1007/s00580-017-2415-5.

24. Nisticò R, Salter E, Nicolas C, et al. Synaptoimmunology — roles in health and disease. Mol Brain. 2017; 10: 26. Available from: https://doi.org/10.1186/s13041-017-0308-9.

25. Liu F, Mccullough L. Inflammatory responses in hypoxic ischemic encephalopathy. Acta Pharmacol Sin. 2013; 34: 1121-30. Available from: https://doi.org/10.1038/aps.2013.89.

26. März P, Cheng JG, Gadient RA, et al. Sympathetic neurons can produce and respond to interleukin 6. Proc Natl Acad Sci USA. 1998; 95 (6): 3251-6. DOI: 10.1073/pnas.95.6.3251.

27. Liu X, Quan N. Microglia and CNS Interleukin-1: Beyond Immunological Concepts Front Neurol. 2018; 9: 8. DOI: 10.3389/ fneur.2018.00008.

28. Gruol DL. IL-6 regulation of synaptic function in the CNS. Neuropharmacology. 2015 Sep; 96 (Pt A): 42-54. DOI: 10.1016/j. neuropharm.2014.10.023.

29. Sparkman NL, Johnson RW. Neuroinflammation associated with aging sensitizes the brain to the effects of infection or stress. Neuroimmunomodulation. 2008; 15: 323-30.

30. Lobo-Silva D, Carriche GM, Castro AG, et al. Balancing the immune response in the brain: $\mathrm{IL}-10$ and its regulation. $J$ Neuroinflammation. 2016; 13: 297. Available from: https://doi. org/10.1186/s12974-016-0763-8. 